\title{
Decomposition and nutrient release in halophytes of a Mediterranean salt marsh.
}

\author{
M.P. Simões, M.L. Calado, M. Madeira, L.C. Gazarini
}

Aquatic Botany 94 (2011) 119-126

\begin{abstract}
This study dealt with the decomposition and nutrient release from the halophytes Atriplex portulacoides, Arthrocnemum macrostachyum, Limoniastrum monopetalum, and Spartina densiflora, the dominant species in the Castro Marim salt marsh, Portugal. Environmental effects on decomposition were also assessed. The study was carried out for one year using the in situ litterbag technique. S. densiflora showed a lower decomposition rate $(k=0.003$ day-1) than the other study species $(k=$ 0.005-0.009). Study species showed similar decomposition patterns, that is, the weight loss mostly occurred during the autumn-winter period (study beginning in November). This indicates that temperature in this period did not hamper the decomposition process. The decomposition rate was positively affected by the initial $\mathrm{N}$ concentration $(\mathrm{r} 2=0.87, \mathrm{P}<0.05)$ and negatively by the $\mathrm{C}: \mathrm{N}$ ratio $(\mathrm{r} 2=0.86, \mathrm{P}<0.05)$ in decomposing materials. At the end of the study, S. densiflora and L. monopetalum, the species with lower initial $\mathrm{N}$ concentrations, retained much higher proportion of initial $\mathrm{N}$ $(89-109 \%)$ than the others (5-14\%). Also, S. densiflora with the lowest P concentration retained higher proportion of initial P (48\%) than the others (5-20\%). Release of $\mathrm{K}$ and $\mathrm{Mg}$ were also slower from $S$. densiflora and was associated with their initial low concentration in this species. The lowest $\mathrm{Mn}$ release was observed from $A$. macrostachyum and also in relation to the lowest initial concentration. Our study supports the hypothesis that decomposition patterns of marsh species are mostly associated with differences regarding their morphology and chemical composition. Given the higher resistance of $S$. densiflora to decomposition, its progressive spreading may result in accumulation of organic detritus overtime in invaded salt marshes.
\end{abstract}

